\title{
Central European Transfusion Medicine - Quality, Guidelines, Laws, Selected Topics of Interest and Future Challenges
}

\author{
Christoph Gassner \\ Zentralinstitut für Bluttransfusion und Immunologische Abteilung, Tiroler Landeskrankenanstalten GmbH, Innsbruck, Austria
}

This issue of Transfusion Medicine and Hemotherapy draws its special attention to Central European transfusion medicine - quality, guidelines, laws, selected topics of interest and future challenges.

Whereas communication between transfusion experts of Germany, Austria and Switzerland has been cultivated since decades, the 'Iron Curtain' and linguistic reasons prohibited a comparable exchange with the 'other parts' of Central Europe (fig. 1). To get over this barrier and considering the recent historical developments such as the enlargement of the EU in 2004, this special issue of Transfusion Medicine And HemoTHERAPY is thought to be an invitation to foster and revive expert discussion among transfusion specialists, especially within Central Europe and adjacent regions.

In this context, transfusion experts of Poland, Czech Republic, Slovakia, Hungary and Slovenia as the five 'Central European representatives' of the ten new EU members, of Bulgaria, Croatia, Romania, Serbia and Montenegro as 'EU candidate representatives' and of Switzerland, Austria and South Tyrol (northern part of Italy) as the 'old Central Europeans' were invited to report on national specifics, especially focusing on up-to-date topics such as quality, guidelines, laws and future challenges [1-8]. German authors [9, 10] contributed overviews about the current EU Blood directive and accreditation needs for medical laboratories in Europe, whereas the author of 'Blood Transfusion in Europe: The White Book 2005 ' [11] gives his view on blood transfusion development within the next 10 years [12].

Taking a glimpse on the articles submitted, certain specific topics were addressed by several authors: cost containment, European self-sufficiency based on a respectful attitude to donors, and the need for compliance with (European) guidelines and laws using quality control as a tool to achieve these demands. Beside lifetime teaching, there is also a need to implement an European scale reflection i) in order 'to put the right person into the right job' and ii) for a better adjustment between training, qualification and professional practice [12]. With respect to first point mentioned above, recent developments in molecular biology, quality control topics, data management, and cost containment led to the employment of a new group of academic experts contributing to the success of modern blood banking. To look at the second point, the classical qualifications of medical doctors, medical technicians, nurses, and administrators experienced a supplementation by molecular biologists, pharmacists, computer scientists, statisticians, and economists. Within the next decade, their responsibilities and competencies need to be defined more clearly in order to recognize their co-operation and grant their teamwork. One should reflect, for instance, in detail on the question whether molecular biologists with a well defined level of experience should be granted a legally defined competency to validate molecular diagnoses within their own responsibility. Beside everyday routine and the implementation of legal issues and guidelines, blood banking as well as every other technology, needs constant improvement and further development. Most of the contributions to this issue come to mention the importance of innovative research for the future development of transfusion medicine. But how and why is research justified? How does research determine its aims? What is its reasonable context? To answer these questions, the understanding of an explicatory model originally developed by economists might help: According to Hinterhuber et al. [13], 'core competency' is the only sustainable attribute delivering customer value. Core competency is in place, if the product is i) of benefit for the customer, ii) rarely encountered, iii) difficult to imitate and iv) not to substitute (fig. 2). Current research is only thought as a servant to achieve and support these four attributes, thereby granting core competency. Therefore, it might well make sense to think about the corecompetencies of modern blood banking and to focus on these

\begin{tabular}{ll}
\hline KARGER & ๑ 2006 S. Karger GmbH, Freiburg \\
Fax +49 7614520714 & Accessible online at: \\
$\begin{array}{l}\text { E-mail Information@Karger.de } \\
\text { www.karger.com }\end{array}$ & www.karger.com/tmh
\end{tabular}




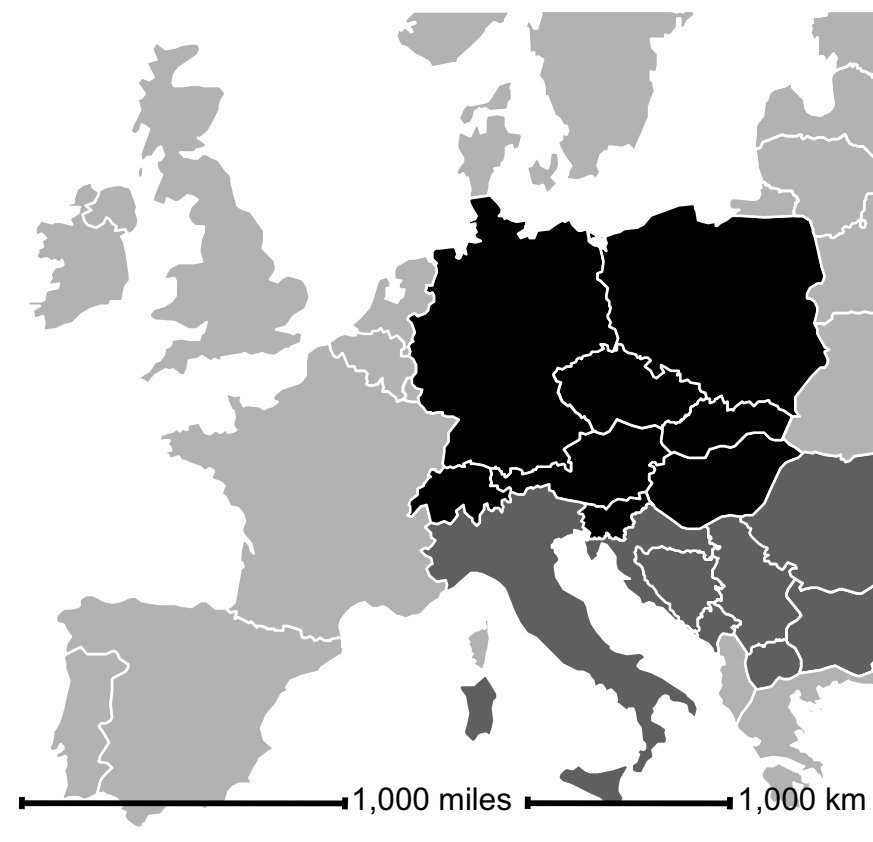

Fig. 1. The term 'Central Europe' is usually used to mean: Germany, Switzerland, Liechtenstein, Slovakia, Poland, Czech Republic, Austria, Hungary and Slovenia, shaded in black. Two additional review reports included in this issue cover reports on Italy and Bulgaria, Croatia, Romania, Serbia and Montenegro, shaded in light gray.

talents for the future, rather than to disperse into to many disciplines. To exemplify, some of our 'block busters' - these customer-beneficial, rarely encountered, imitation-resistant and unreplaceable products - might be defined as 'cell therapeutics' (erythrocytes, platelets, etc.), others as the interrelated discipline-specific knowledge e.g. about the erythrocyte sur-

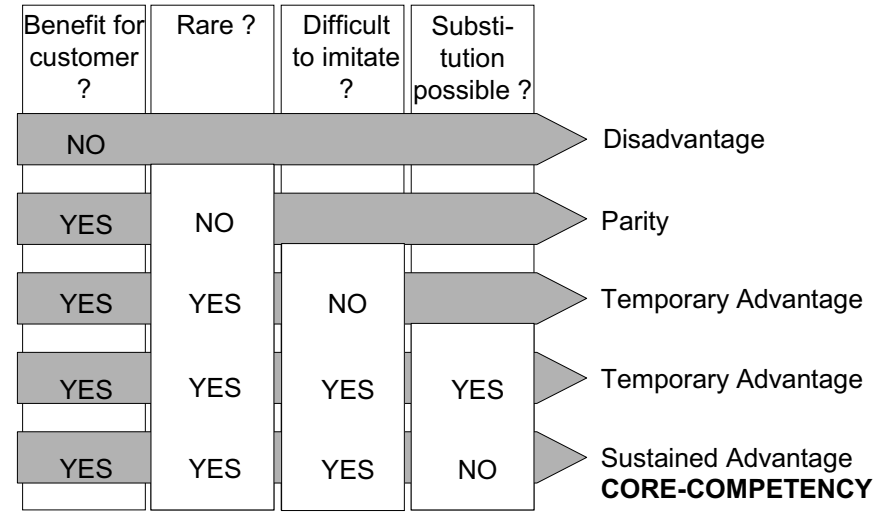

Fig. 2. Core-competency is in place, if the product is i) of benefit for the customer, ii) rarely encountered, iii) difficult to imitate and iv) not to substitute. The presence or absence of respective attributes leads to gradually improving market relevance.

face (blood groups). However defined, core competencies are obviously important and their sustaining research needs to be managed with diligence.

Since financial resources are limited and the future challenges for innovations are numerous, the formation of cooperative networks is of great importance for active contributors in this field. Therefore, thinking in international benchmarks (rather than regional or national) will become an important topic. Primarily however, the previous excursion into the theories of research was mainly meant as a reflection about the conditions for the evolution and innovation of our current products and services since one important fact has to be kept in mind: it is the management, e.g. quality-control, guideline issuing and law enacting, which finally serve our products and services and not vice versa. First there is the product, then management.

\section{References}

1 Antoniewicz-Papis J, Letowska M: Polish blood transfusion service - quality, guidelines, laws, selected topics of interest and future challenges. Transfus Med Hemother 2006;33:401-406.

2 Zimová R, Turek P: Blood transfusion service in the Czech Republic - organization, regulation and guidelines, quality and safety, perspectives and challenges. Transfus Med Hemother 2006;33: 407-414.

3 Barotine-Toth K, Hoffer I: Hungarian national blood transfusion service. Transfus Med Hemother 2006;33:415-419.

4 Rožman P, Domanović D: Transfusion medicine in Slovenia - current status and future challenges. Transfus Med Hemother 2006;33:420-426.
5 Hafner V, Dobrota A, Sarlija D, Rasovic G: Quality and safety of the national blood supply: a priority for action - subregional overview Bulgaria, Croatia, Romania, Serbia and Montenegro. Transfus Med Hemother 2006;33:427-431.

6 Levy G, Byland C, Niederhauser C, Schwabe R, Senn M, Mansouri Taleghani B: Transfusion medicine in Switzerland. Transfus Med Hemother 2006; 33:393-400.

7 Schennach H, Gabriel C, Schönitzer D, Blauhut B: Transfusion medicine in Austria. Transfus Med Hemother 2006;33:364-373.

8 Lanthaler J, Mitterer M: Transfusion medicine in South Tyrol. Transfus Med Hemother 2006;33: 432-436.
9 Listl S, Klouche M: The European Blood Directive (Directive 2002/98/EC) in the context of European Community legislation. Transfus Med Hemother 2006;33:374-383.

10 Spitzenberger F, Edelhäuser R: Accreditation of medical laboratories in Europe: statutory framework, current situation and perspectives. Transfus Med Hemother 2006;33:384-392.

11 Rouger P, Hossenlopp C: Blood Transfusion in Europe: The White Book 2005. Paris, Elsevier, 2005.

12 Rouger P: Blood transfusion development within the next 10 years. Transfus Med Hemother 2006; $33: 437-440$

13 Hinterhuber HH, Handlbauer G, Matzler K: Kundenzufriedenheit durch Kernkompetenzen, 2. Aufl. Wiesbaden, Betriebswirtschaflticher Verlag Dr. Th. Gabler, GWV Fachverlage, Germany, 2003. 